\title{
Social-Economic-Political-Emotional (SEPE) Factors Regulate Human Growth
}

\author{
Barry Bogin ${ }^{1}$ \\ ${ }^{1}$ University of California San Diego / Salk Center for Academic Research and Training in Anthropogeny (carta.anthropogeny.org), School of Sport, Exercise \& Health \\ Sciences, Loughborough University, UK.
}

\section{Citation:}

Bogin, B (2021), Social-Economic-PoliticalEmotional (SEPE) Factors Regulate Human Growth, Human Biology and Public Health 1. https://doi.org/10.52905/hbph.v1.10.

Received: 2020-12-18

Accepted: 2021-01-23

Published: 2021-06-22

\section{Copyright:}

This is an open access article distributed under the terms of the Creative Commons Attribution License which permits unrestricted use, distribution, and reproduction in any medium, provided the original author and source are credited.

\section{Conflict of Interest:}

There are no conflicts of interest.

\section{Correspondence to:}

Barry Bogin

email: b.a.bogin@lboro.ac.uk

\section{Keywords:}

prestige, dominance-subordination, social identity, ego motivation, material and moral conditions, community effects

\begin{abstract}
Background There is a recurring and seamless interaction between the biology of human development and the social-economic-political-emotional (SEPE) environment. The SEPE environment influences the quality of the material conditions for human biology and, simultaneously, human growth in height and other dimensions provide social and moral signals that provide information to community networks.

Objectives This article reviews the role of SEPE factors in human growth, especially skeletal growth.

Sample and Methods The meaning of SEPE is defined and shown to be related to individual and group prestige, to social identity, and to ego and task motivation. These influence dominance or subordination of communities and the material and moral conditions of societies. Historical and contemporary examples of SEPE effects on skeletal size are presented.

Results Membership in a SEPE community impacts skeletal size in height and breadth. Higher SEPE classes are taller, lower SEPE classes are broader. In elite level sport the winners have more growth stimulation via the hormone IGF-1 even before the contest. These findings are explained in terms of dominance versus subordination and the Community Effect in Height hypothesis.

Conclusions SEPE factor regulation of human growth is shown to be a more comprehensive explanation for plasticity in height than traditional concepts such as socioeconomic status and simple-minded genetic determinism. People belonging to upper SEPE class communities, the elites, know that they are superior and are treated as such by the non-elites. The material and moral condition for life operating through these community social networks provide positive stimulation for the elites and negative stimulation for the lower SEPE classes. These differences maintain the gradients in height between SEPE communities in human societies.
\end{abstract}

Take home message for students The basic pattern and stages of human growth are shared by all living people and are the outcomes of the evolutionary history and biocultural nature of our species. Socialeconomic-political-emotional (SEPE) factors are created by every human culture and these factors create material and moral conditions that impact human growth. 


\section{Introduction}

The basic pattern and stages of human growth are shared by all living people (Figure 1). This pattern is the outcome of the four-to-seven-million-year evolutionary history of the hominins - living human beings and our bipedal fossil ancestors. The way each human being grows within the basic pattern is the product of an interaction between the biology of our species, the material-physical environment in which a person and his recent ancestors live, and the social-economic-political-emotional (SEPE) factors that every human culture creates. Thus, human growth and development reflect the evolutionary history and biocultural nature of our species (Bogin 2021).

\section{SEPE Factors}

This article focuses on the SEPE factors. I have been developing the concept of SEPE factors since 1974, when I began my research on human growth in Guatemala. Since then my research took me to projects in Mexico, the United States, South Africa, Portugal, the United Kingdom, and Spain. Participants in the research were from these countries or were immigrants from Guatemala, Cape Verde, and Bangladesh. The geographic and cultural diversity of the people who graciously agreed to participate in the research had much impact on me professionally and personally. From my interactions with them and from learning about their countries of origin and their lives I came to appreciate the central role that SEPE factors have in human growth and development.

Why do I associate the words 'social-economic-political-emotional'? Why not use
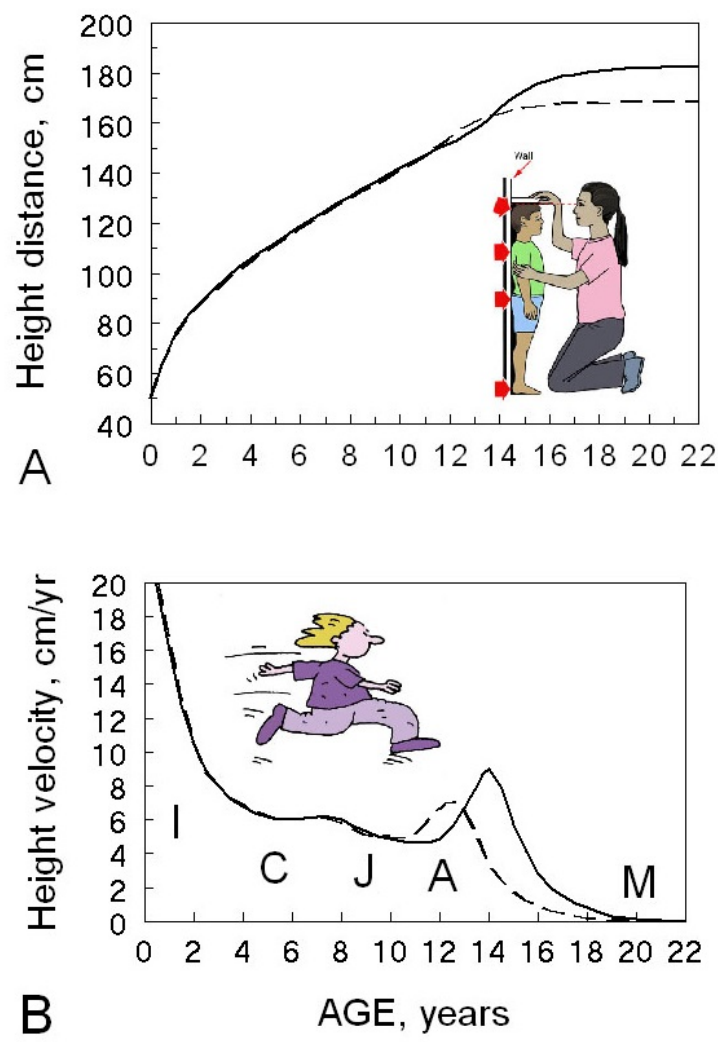

Figure 1 The basic pattern of human growth. Average distance (A) and velocity (B) curves of growth in height for healthy girls (dashed lines) and boys (solid lines). Distance is the amount of height achieved at a given age. In part $A$, the image shows a child's height being measured. Velocity is the rate of growth at a given time, in this case shown as centimeters per year. In part B the running figure represents "velocity." The velocity curves show the postnatal stages of the pattern of human growth. Note the spurts in growth rate at mid-childhood and adolescence for both girls and boys. The postnatal stages: I, infancy; $C$, childhood; J, juvenile; $A$, adolescence; $M$, mature adult. The average values shown in this figure are based on northern European girls and boys. While almost all healthy, full-term newborn humans average $\sim 50 \mathrm{~cm}$ in length, with a range of 48-52 cm, amounts and rates of growth soon begin to vary both within and between populations. The average adult height of women and men across 202 nations and territories of the world (no Pygmy groups) has a range of $20 \mathrm{~cm}$ for women and $23 \mathrm{~cm}$ for men (NCD Risk Factor Collaboration 2016). Original figure, B. Bogin.

the more common and simpler phrase 'socioeconomic status'? Why not other words such as 'cultural,' 'ethnic,' 'religious,' or 'psychological'? The choice of words is based on empirical data collection, descrip- 
tive analysis of those data, and inferential research leading to hypothesis formation. That process began in the $19^{\text {th }}$ century and was brought into sharp focus by Franz Boas (1858-1942) and Henry P. Bowditch (1840-1911) who analyzed the growth of New York City and Boston school students (Bowditch 1877; Bowditch 1891; Boas 1892; Boas 1912). They considered the health and nutritional status of the children, juveniles, and adolescents and concluded that these factors were important, but even more important determinants of body size and body shape (e.g., relative leg length, head shape) were the family circumstances of the students. The migration history of the families, that is, whether the students were themselves immigrants or the second or third generation born in the United States, was a more powerful determinant of growth than the nature of the diet or recent health history.

At the time of Bowditch and Boas, as is the case today in virtually all nations, there were passionate discussions about the politics of immigration. Social prejudice against immigrants was often converted into economic and political policies of discrimination against more recent immigrants. These social-economic-political attitudes and policies created inequities in living conditions related to housing, education, and employment. Bias and inequality create insecurity and emotional stress, which are most strongly felt by those who are most subordinate in a society but are also experienced by those higher on the ladder of dominance because of real or perceived threats, such as criminality or violence, from those lower on the ladder (Hermanussen et al. 2017; Hermanussen and Scheffler 2016). Even more threatening than violence is the fear that the children of subordinate parents may grow-up to 'stealaway' the privileged status of the children from families with middle-to-higher dominance. The net result is the creation of
SEPE factors that impact the conditions of the material-physical environment in which people live and their biological wellbeing.

The subordinate or dominant status of people in a society is related to the concept of socioeconomic status (SES) but not identical to SES. In its most widespread usage, SES is a concept devised by the social scientists, statisticians, and the governmental tax authorities ${ }^{1}$ to measure some aspects of education, occupation, and social prestige of a person or a social group. One early usage was by the psychologist Raymond Cattell (1905-1998) who claimed that the essence of socioeconomic status was the "prestige factor" (Cattell 1942). Prestige was derived from a person's occupation and was more important than income, property, or education, but prestige was highly correlated with these. Cattell (1942, 300) wrote that

"Social status, in short, is a purely psychological entity. Such a statement must not be taken to mean that it is not

1 Governments use socioeconomic status to target taxes on everything from income and luxury goods to taxes on addictive products such as tobacco and sugary drinks. In the United States, Mexico, and some other nations, people of lower SES tend to use more of the addictive products. To discourage overuse, governments tax these products. There is another purpose of the taxes on these products - to increase revenue to the government. People of lower SES often earn less money and pay less income tax. Lower SES people purchase fewer expensive items such as houses, boats, and other luxury goods that are taxed at relatively high levels. As lower SES people make up the predominate share of the population (e.g., $\sim 30 \%$ of the population in the USA is in poverty or near poverty and $44 \%$ of the population in Mexico live below the poverty line) taxing the products that these low SES people use is one effective means to increase revenue. References: USA, Haymes et al. (2017); Mexico, www.telesurenglish.net/news/In-Mexico-7-out-of-10-Born-in-Poverty-Will-Die-inPoverty-20180509-0008.html (Last accessed: 9 May 2018). 
real or that it cannot be measured or that it is not a precisely definable concept. It is to be defined and measured in terms of behavior, implying mental states behind behavior. The prestige of an occupation is resident in the minds of all people in the community and is to be measured by assessing their attitudes towards it at a given time."

A key concept added by Cattell is that prestige, and its socioeconomic status, is measured by the people of a community - it is a community effect. Community effects on physical growth, development, and maturation have long been observed in human and non-human animal research (Bogin et al. 2018; Huchard et al. 2016; Schell et al. 2009). Another key point made by Cattell is that effects of SES and prestige begin as a 'psychological entity,' that is, as an emotion or feeling. Cattell's observations on the emotional power of prestige have been applied to a newer understanding of the regulation of growth in body size that includes an understanding of competitive growth strategies and community effects on height (Hermanussen et al. 2019; Hermanussen et al. 2020). Competitive growth strategies, also called strategic growth adjustments, relate to the empirical observations in many animals, including non-human and human primates, that larger/taller individuals tend to enjoy the premium social position among other members of their social groups and that when young and still growing those who are destined to achieve premium position grow bigger/taller.

SEPE factors, including feelings of prestige, also relate to the community effects in height hypothesis, that membership in a social network tends to equalize the height variance of its members. Additional major factors regulating height between competitive individuals and the height of communities are: 1) dominance-subordination, 2) social identity, 3) ego motivation, and
4) task motivation. These italicized terms are defined and described briefly in Text Box 1. Also presented in the Text Box are examples of how these height regulating factors interact. The point to emphasize here is that the impacts of dominancesubordination, social identity, and ego and task motivation are transduced in the brain from social-emotional experience and into hormonal activity of the pituitary, hypothalamus, and other neuroendocrine tissues within the brain. The endocrine outputs of these brain tissues directly regulate physical growth, resulting in strategic growth adjustments and/or community effects in height.

Text Box 1 Definitions and brief description of the terms strategic growth adjustments, community effects, dominance-subordination, social identity, ego motivation, and task motivation. Further discussion is found in the main text. Strategic growth adjustments (also referred to as competitive growth strategies) - refer to changes in body size or rate of growth that are associated with position in the social hierarchy. As used by mammalian biologists, the phenomenon of strategic growth adjustments involves changes in growth rates to achieve larger body size or grow to adulthood at a faster rate to achieve social and reproductive dominance. These are most often observed in cooperatively breeding mammal species where reproduction is virtually limited to the most dominant female and male individuals (Huchard et al. 2016; Clutton-Brock 2016). Competition between litter mates for dominance acquisition often involves changes to achieve larger body size, growth to adulthood at a faster rate, and the presence of secondary sexual characteristics that advertise dominance and fertility. Loss of social dominance is often associated with post-adulthood body size reduction and/or the loss of secondary sexual characteristics. These somatic characteristics have been observed in many non-primate mammals including African monkeys and orangutans (Maggioncalda et al. 2002; Sapolsky and Spencer 1997; Setchell 2016; Emery Thompson et al. 2012). A human example is described for Polish school students with fathers and grandfathers belonging to different social mobility groups (Koziel et al. 2019). The researchers considered three generations, the school students (6 to 18 years old), their fa- 
thers, and their grandfathers. The three generations were dichotomized into 'lower SES' and 'higher SES' according to grandfathers' occupation and according to fathers' education. The researchers compared the two non-socially mobile groups (grandfathers and fathers stayed in the same lower or higher SES category) and the two with socially mobile histories (SES of fathers and grandfathers differed). The authors found that, as expected, higher SES men, both grandfathers and fathers, were taller than lower SES men. Moreover, the SES effect on height persisted into the third generation of school students. The novel findings were that upward social mobility of the fathers, measured by lower SES fathers who received secondary or university education, resulted in taller stature both in these men and in their children. The opposite effect applied to fathers and their children with downward social mobility. In this case, the sons of higher SES grandfathers received only basic or vocational education. These less educated fathers lost their social advantage and their growth, and that of their children, was adjusted downward toward that of the lower SES group. The authors concluded that the SES effect on height tends to persist across generations, “...but depends on education. Upward social mobility measured as a "better" education, results in taller stature, up to the third generation" (Koziel et al. 2019). Community effects in height- a hypothesis that social interaction between members of the same group leads to similarity in growth of height. Humans are social; social communities rely on signals. Human height is a powerful signal of status, prestige, health, and competence (Hermanussen et al. 2019; Stulp et al. 2012). Membership in a community involves social interaction within the network of its members. The effect on height is to reduce the statistical variance between members within the network. The hypothesis is based on well-documented research that social networks within communities tend to equalize variance in body weight and body composition, for example, overweight people tend to have overweight friends. Social networks also have similar impacts on neuroendocrine physiology (Bogin et al. 2018; Ponzi et al. 2016; Martire and Franks 2014; Christakis and Fowler 2007; Koehly and Loscalzo 2009). The convergence of these biological and health characteristics toward the community 'average' arises from the biological-social-psychological proximity of members within a shared network. Human societies can be viewed as networks that can be characterized by nodes (individuals, groups of people, villages, towns, or cities) and edges con- necting the nodes. A network analysis and formal definition of community effects in height was provided by Hermanussen and colleagues in their report on the height distributions of Swiss military conscripts (Hermanussen et al. 2014; Hermanussen et al. 2016). The researchers used Monte Carlo simulations of body height in both real and artificial networks to show that spatial distance along edges that connect nodes can affect height clustering. In this case, the edges were measured as the distance travelled by road between the home districts (nodes) of the conscripts. The researchers considered Switzerland as a geographic network (Figure 2) with 169 nodes (district capitals) and 335 edges (connecting roads) and studied effects of connectedness on height in Swiss men conscripted in 1884-1891, 1908-1910, and 2004-2009. The significant associations were explained by road distance between districts. There were no significant correlations between mean height in a district and body mass index (nutrition), population density (rural/urban), or altitude above sea level (oxygen saturation). Height in a district depended on height of physically connected neighboring districts. The association decreased with greater road distance in the network. The researchers suggested that people can be short because their neighbors are short, or tall because their neighbors are tall due to community effects on growth mediated by emotional and neuroendocrinological growth regulators. Similar findings have since been reported from analyses of Norwegian, Polish, and Russian conscripts (Bents et al. 2017; Gomula et al. 2017; Lebedeva et al. 2019).

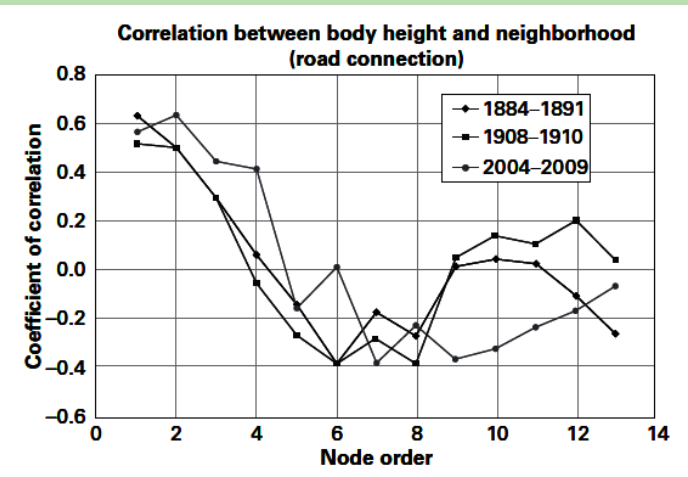

Figure 2 The correlation in height of Swiss military conscripts between neighboring districts. Significant height correlations ( $p<0.01)$ exist between first, second, and third order neighbors in conscription cohorts of 1884-1891, in 1908-1910, and in 2004-2009 ( $<$ 0.01); in the 2004-2009 cohort significant correlations in height were found up to fourth order neighbors. Figure adapted from Hermanussen et al. (2014) with permission of the authors. 
Dominance-subordination - describes social relationship in groups in which higher ranking members (dominant) have priority of access to resources over lower-ranking members (subordinate). The resources may be material items such as food and living space. But, even in situations of material equality dominant individuals usually have priority access to SEPE factors. The priority of the dominant is a powerful emotional force that supports feelings of higher prestige, of self-worth, and of respect from subordinates. A prime example of is the analysis by Komlos and colleagues (Komlos et al. 1992) of the growth of German boys attending the Carlsschule in Stuttgart in the $18^{\text {th }}$ century. The pupils of this boarding school included sons of the nobility (the high aristocracy), the low aristocracy, and the lower status bourgeoisie. Between the ages of 6-23 years the boys were measured at irregular 3-12 monthly intervals. Measurements took place from the year 1771 to 1793 (Figure 3). At 18 years of age, mean height of all boys was $165.2 \mathrm{~cm}$ (min. $147.4 \mathrm{~cm}$ - max. $182.6 \mathrm{~cm}$ ). The median height of 18-year-old boys in Germany in 2016 was $179.9 \mathrm{~cm}$ (NCD Risk Factor Collaboration 2016), so the Carlsschule boys were quite below average for today. Even so, the boys of the high aristocracy were some 10 to $15 \mathrm{~cm}$ taller and matured 1-2 years earlier than their low aristocratic and bourgeois classmates. During the school year all the boys shared lifestyle and the same nutritional conditions. They slept in the same dormitories, so were exposed to the same illnesses and pathogens. More to the point, all the boys knew their own social status and the status of the others. The boys knew that they belonged to different social status communities and it seems likely that this knowledge produced emotional effects on growth regulation so that the boys grew in height according to their ranking in terms of dominance or subordination. The likely mechanism for this effect is that the social dominance of the higher-class boys imposed emotional and physical stress on the lowerclass boys that altered hormonal profiles and repressed their height growth. There is supportive evidence for this mechanism from studies of living people and non-human mammals and some of these studies are described in the main text.

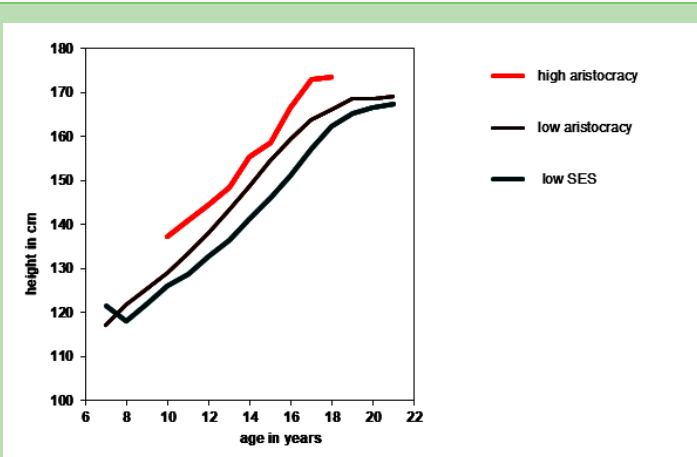

Figure 3 Mean heights of Carlsschule students measured in the years 1771-1793. Based on data in Komlos (1992).

Social identity - refers to a person's sense or feeling of distinctiveness and self-worth based on perceptions of membership in one or more groups. The concept is credited to Henri Tajfel and John C. Turner (Tajfel and Turner 2004) (reprint of 1986 article). The central hypothesis of social identity theory is that members of an in-group will seek to find negative aspects of an out-group, thus enhancing their self-image. Tajfel and Turner's goal was to develop a theory of intergroup conflict and it is noteworthy that the focus of this theory has shifted over time from the social psychology of individuals to a new field of political psychology of groups. The focus on SEPE factors in the present discussion builds on Tajfel and Turner's pathbreaking ideas. Tajfel and Turner emphasized "group identification" and "identity signaling" as mechanisms to facilitate in-group favoritism, and shape common goals and social norms. Conflicts of group interests not only create antagonistic intergroup relations, but also heighten identification with, and positive attachment to, the in-group. In relevant intergroup situations, individuals will not interact as individuals, on the basis of their individual characteristics or interpersonal relationships, but as members of their groups. Tajfel and Turner brought our attention to the process whereby people derive a sense of self-worth and social belongingness from their memberships in groups. People will then see their group and themselves favorably and see other groups as superior, inferior, or competitive to their own group depending on the SEPE resources and social position that each group controls. Social identity theory is the basis for explaining feelings of xenophobia and dislike of 'others' and is part of the understanding for community effects in height, strategic growth adjustments, and dominance-subordination.

Ego motivation \& task motivation - are psychological-emotional states that underlie, in part, social identity theory. The concepts of ego motivation 
and task motivation are most often used by sport psychologists to explain goal orientations (Duda et al. 1995). Ego oriented goals and motivations are set by the athlete who compares herself with similarly skilled athletes and bases her success on doing better than her opponents. More generally, ego motivation is promoted by considering oneself as being more skilled than other individuals and putting more emphasis on winning a contest over an opponent rather than developing one or more skills. Ego motivation and goals are about being better than others by having better resources. For athletes this may be better sport equipment. For the general population this may be better education and/or social position. Ego motivation in sports is also enhanced by possessing better innate ability and more luck than others. In the general population, taller individuals and/or those of higher social status believe they have greater innate ability than shorter people and those of lower social status (Stulp et al. 2015; Stulp et al. 2012).

Task oriented goals and motivations, in athletics and in general social practice, are about mastering a skill or undertaking. By mastering the required skills the person feels competent with her ability to perform on the playing field or social arena. An emphasis on task motivation indicates that people evaluate their success and self-worth by effort and improvement, by collaborating with other members of the team, with other members of the social in-group, and by doing one's best. People with social identity within dominant groups tend to have both high ego and task motivation-orientation goals. Having these attitudes leads to an ability to master many SEPE skills and builds confidence to perform well in society, even to the desire to out-perform opponents and members of out-groups. This includes growing taller than the members of socially subordinate groups. The growth differences between the Carlsschule and higher versus lower SES Polish students, their fathers, and their grandfathers are examples.

\section{SEPE Factors and the Material \& Moral Conditions of Society}

The concept of SES is part of the SEPE factors hypothesis for human growth regulation. SES, however, does not capture the nature or causes of strategic growth adjustments and community effects in height. As used by many researchers today SES also fails to capture the emotional nature of prestige and its impacts on dominancesubordination, ego motivation, and task motivation. SEPE goes beyond SES to capture these by addressing the material and moral conditions of the community and larger society. The role of material and moral conditions on physical growth was observed by James M. Tanner (1920-2010), a growth researcher and historian of social medicine. Tanner stated that human growth provides a 'mirror' of the human condition, reflecting the "[...] material and moral conditions of that society" (Tanner 1987). These material and moral conditions have joint, interactive impact on the growth and development of young people. Ever since Tanner, the 'growth as a mirror' metaphor has been widely used (LópezBlanco 1995; Sikdar 2015).

Inherent in the SEPE factors hypothesis of human growth are the "material and moral conditions' of a society or nation, and it is the importance of those conditions which further justifies the association of the words 'social-economic-political-emotional.' Within the SEPE factors perspective there are testable hypotheses about the regulation of human growth. The following is a list of how each SEPE term relates to prestige, dominance-subordination, ego motivation, material and moral conditions, and citations to the hypothesis testing:

- Social refers to the community, to the network of all things ranging from material items to moral imperatives that are communal and shared by groups of people, even nations, operating in private and public arenas. The material-to-moral assets of social networks and the differences in prestige dominance-subordination, social identity, and ego motivation of people within the network create much 
of the living conditions of their community. This Social aspect of SEPE is formalized in tests of the community effects hypothesis (Bogin et al. 2015; Bogin 2021).

- Economic - refers to the financial and monetary basis of community, social network, and nation. Anthropological research finds that all human groups have economic systems, including pre-industrial societies such as foragers (gatherer-hunters), pastoralists, horticulturalists, and pre-industrial, hierarchical state societies (e.g., ancient Egypt, Rome, Aztec, Maya, Vedic, and African Kingdoms of Kush and Zimbabwe; medieval Europe, China, Japan). The economic aspect of SEPE focuses on production of goods and services, trade and costs, and the degree of inequality in these that create distributions of wealth or poverty. These have direct bearing on material and moral foundations of a society and the prestige, dominance-subordination, and social identity of its members. Marcel Mauss wrote eloquently and passionately about these in his book The Gift (Essai sur la don, 1967). This book is a sociological/anthropological classic on the economics, politics, and morality of exchange in non-Western and ancient societies. People everywhere possess a fantastically detailed 'mental ledger' of exchange and according to Mauss this is because the purpose of exchange is not to amass 'profit', but rather to amass prestige and to ward-off moral turpitude, that is, acts or behaviors that violate the accepted standard of the community. A person avoids moral transgression and accrues greater social identity, prestige, and dominance by meeting responsibilities for economic, political, religious, and ethical obligations.
Two hypotheses have been tested to show important associations between economics and human biology in early modern and modern communities. The first is the hypothesis that greater average height is the result of greater economic well-being of a community (Komlos 2009; Steckel 2017). This hypothesis is often framed in terms that a premium economy leads to a premium body size via better nutrition and/or reduced infectious disease. The economists derived the nutrition/health hypothesis from mid-to-late $20^{\text {th }}$ century proposals offered by nutritional epidemiologists and public health workers. Some of the researchers were employed or supported by international processed food corporations or the pharmaceutical industry (Scheffler et al. 2020; Solomons 2019). Other researchers received their funding from government agencies dedicated to food and infectious disease control as part of political programs. Nutritional adequacy is, of course, essential to health and physical growth. However, most of the economists and other researchers were either unaware or had forgotten the early $20^{\text {th }}$ century research that found little to no association between quality of the diet and growth in height (Hermanussen et al. 2018). That earlier research has been reaffirmed by systematic reviews and meta-analysis of nutrition interventions to prevent height stunting (Goudet et al. 2019). The role of infectious disease in height growth is also questioned by reviews of water, sanitation, and hygiene (WASH) interventions (Allen et al. 2013). These $21^{\text {st }}$ century reviews cast much doubt on the hypothesis that 'better' diet and health are the primary drivers of greater average height for a group of people. The SEPE factors hypothesis offers a more parsimonious explanation for height variation between social and economic groups of people.

The second economic hypothesis to be tested is that greater equality of income dis- 
tribution results in greater average height of a nation or societ (Baten and Blum 2012; Bogin et al. 2017; Mumm et al. 2017). This hypothesis addresses more directly the SEPE conditions under which the people live. The research reports that, in general, global variation in adult height is better predicted by a measure of income inequality, such as the Gini coefficient, than by the more commonly used economic measures of absolute income, such as the gross domestic product or the gross national income adjusted for purchasing power parity. The poor live in poverty (low income), which is a direct cause of suffering. But social inequality has more powerful impacts on human biology and well-being because most people in modern nationstates exist along a gradient of access to material \& moral resources. That gradient is determined by social, educational, and occupational prestige as much or more than income. The social prestige differences not only influence income and wealth, but also decisions and behaviors related to diet, health care seeking, smoking, alcohol consumption, sexual activities, educational attainment, and other similar variables that are associated with physical growth. There is also evidence that the social prestige differences themselves influence neuroendocrine activity that regulates growth in height (reviewed below). Testing economic hypotheses about gift exchange, moral obligations, and prestige in relation to growth in height or other physical dimensions remains to be done.

- Political aspects of SEPE refer to the organization of social power and its use to control access to material resources by a community or nation (Marmot and Bell 2012; Sen 2002; Liebig 2012). Political power is closely related to the prestige and moral attributes of the economics of SEPE. The anonymous author(s) of the Old English epic poem Beowulf,dated to about the year 1000 ACE, wrote, "Behaviour that's admired is the path to power among people everywhere" (Heaney 2000, 5). All human societies, past and present, have well-developed systems of political power. Anthropologists recognize four general types of societies. Band and tribal societies (foragers, pastoralists, horticulturalists) are often more egalitarian, with no one person, family, or group having dominant power. Chiefdom and state societies have hierarchies of power with a concentration of power in some dominant groups, resulting in the subordination of other communities or groups. Political power systems may be regulated by moral codes or codified legal rules and enforced by social identity and social cooperation, or by coercion via dominance-subordination, threats of economic sanctions, or violence (imprisonment, physical punishment, police/military action). In addition, ego motivation underlies the quest for power by some individuals.

There are many tests of the relationship between political power, height, muscularity, and fatness in the literature. Most often found is that both greater height and muscularity are associated with likelihood to win social or physical contests and achieve greater political power (Bogin 2021; Rueden et al. 2008; Stulp et al. 2015). Much research reports that people with greater fatness tend to be of lower SES, earn less money, perform less well in school, and are less likely to win social-political contests (https://www.hsph.harvard.edu/obesityprevention-source/obesity-consequences/ ). Stulp and colleagues (Stulp et al. 2013) analyzed physical growth data for candidates of all United States presidential elections and found that height is a factor in success. Firstly, presidents were, on average, $7.23( \pm 7.10) \mathrm{cm}$ taller than men from 
the same birth cohort. Secondly, taller candidates received more popular votes than their opponent, but did not more often win the election. Thirdly, if the sitting president was taller than his opponent, then he was more likely to be reelected. As all presidential candidates are adults and not growing in height, their tallness likely preceded their rise in political power. Of course, the social and economic position of their families were likely factors influencing their growth to a strategically taller height. There are a few tests of the strategic growth hypothesis in relation to political aspects of SEPE (Boas 1912; Hermanussen et al. 2017). Findings of these studies indicate a dual direction of causality, in that 'height causes success' and 'success causes height.' As people are growing, their social identity with a successful community, the dominance-subordination of their community, and their levels of prestige regulate amounts and rates of growth

- Emotional aspects of SEPE refer to feelings, desires, fears and hopes that people and their communities have for themselves, their offspring, and subsequent generations. These feelings stem from the degree of social identity and material security that people have which, in turn, stems in large part from the moral and legal codes of the community and larger society. Such feelings may interact with ego motivation to seek prestige and affect the dominance-subordinance position of individuals or communities. The central place of emotional factors in human growth and development is supported by research demonstrating growth failure and development delays when infants and children are denied affection, touch, and love by their family and community (Bogin 2021; Rogol 2020). As early as the year 1701 there was clear evidence of a relationship between the psy- chosocial environment and human physical development (Peiper 1955). Research in the $20^{\text {th }}$ century demonstrated the importance of physical touch and love to prevent neonatal mortality and promote good physical and mental development (Harlow and Zimmermann 1959; Meyer et al. 1975; Spitz 1945; Field 1988; Field 2007). Some of the current hypothesis testing of emotional regulation of human growth focuses on maternal stress during pregnancy, family disruption via parental separation, international migration and adoption, sibling competition, and emotional impacts of climate change (reviewed in Bogin (2021), see especially chapters 7 and $8)$.

\section{Two Examples of the Role of SEPE Factors Regulating Human Growth}

\section{Example 1 - Higher SEPE classes are taller, lower SEPE classes are broader}

Does human growth and development respond to the community effects of social psychological proximity and similarity of SEPE factors? The answers seem to be "yes"! In 1925, Schlesinger reviewed then current knowledge in a chapter titled "The influence of the social environment on the growth of the children" (der Einfluss des sozialen Milieus auf das Wachstum der Kinder). He explicitly mentioned the shorter but stouter body of children of the lower social class of cities and of rural children compared with children of higher social class, who were taller and thinner. In his textbook Growth at Adolescence, Tanner (1962) reviewed several German 
and British studies that reported similar differences. Tanner wrote, "[...] there is evidence that the upper socio-economic classes have less weight-for-height than the lower ones, and are therefore more linear [...]" (p. 140). None of the studies reviewed by Tanner could find differences in fatness between children of the upper and lower social classes before puberty. Tanner concluded that, "The greater weight for height of the less favoured groups seems to reflect a greater breath of skeleton and perhaps also muscles; or put another way, a lesser growth of the skeleton in length for its breadth" (Tanner 1962, 140). Tanner speculated that part of the difference might be nutritional, but he discussed at greater length the impact of social class itself on growth in height vs. width. After all, neither nutrition nor infection can explain why upper-class children grow more in skeletal length, but lower-class children grow more in skeletal width (e.g., shoulder or pelvic breadth) and have more muscle. Could this be a community effect interacting with a trade-off in where skeletal growth takes place? It seems that upperclasses grow to a SEPE community norm of tallness, with a trade-off in less skeletal breadth, while lower-classes grow to a SEPE community norm of robustness, with a trade-off of shorter stature.

Tanner also speculated that the social class differences arose from societal biases in education and occupation that promoted the taller, but less skeletally robust, to move up in social class while the shorter, if more robust, moved downward. In the 1999 edition of Patterns of Human Growth I reviewed research showing this is certainly true (Bogin 2005, 324-328) and I concluded that the concrete result of these biases, just as for the discrimination stemming from racial prejudice, is that individuals or groups of the accepted "type" are more likely to receive better treatment in terms of all four domains of SEPE (social, eco- nomic, political, and emotional domains) than individuals or groups of the undesired type. A positive feedback relationship between growth and SEPE status results from the social bias, in a three-step fashion: 1) exposure to better material and moral SEPE conditions lead to social identity with the dominant social groups, feelings of both ego and task motivation toward one's own superior competence, greater prestige, and taller height; 2) taller individuals tend to rise further in SEPE status; and 3) greater height and higher SEPE status lead to even better material, moral, and emotional conditions for growth. An opposing cycle exists for those from lower SEPE status, especially those with below average stature, or individuals considered 'too short' from any SEPE class. The result is that differences in physical size between individuals are both a consequence and a cause of SEPE effects on growth.

Readers of this article should be asking, "Why would higher SEPE status increase height but not skeletal breadth?" It seems reasonable to expect that better SEPE living conditions would enlarge the skeleton in all directions. In fact, this is not a reasonable expectation because it would result in biomechanical difficulties for body form and function. Early $20^{\text {th }}$ century researchers such as D'arcy Wentworth Thompson in his book On Growth and Form (1917; 1942) and Julian Huxley in his book Problems of Relative Growth (1932) documented the evidence for the allometric regularities in the growth of plants and animals that were required to maintain biomechanical function. As applied to human growth, allometric regularities in body height and skeletal breadth have been described in several geographically and socially diverse populations. Reviews of some of these studies were provided by Christopher Ruff (1994; 2002) who cites studies of Japanese in Japan and in Hawaii. In Japan, Takahashi (1986) reported that 
during the $20^{\text {th }}$ century there was trend for later cohorts of adolescent and young adult women to be taller but not have greater body mass. Takahashi hypothesized that the 'thinness' of the women was due to a desire to be slim and maintain low body fat. Analysis of the women's skinfold thicknesses found no trend in loss of body fatness. Ruff suggested that skeletal body breadth did not increase as fast as stature did with each new generation. Takahashi did not measure skeletal breadth but Froehlich (1970) did so in a study of Japanese-Americans living in Hawaii. He reported a negative allometry between greater height and narrower bicristal (pelvic) breadth between generations. Similar results were reported for Belgian boys and girls (Vercauteren et al. 1998).

The negative allometry between greater height and narrower pelvic breadth is noted even among the higher SEPE class of the United States. Gordon T. Bowles (1904-1991) measured several anthropometric dimensions of matched pairs of fathers and sons who attended Harvard University and mothers and daughters who attended the elite Ivy League women's universities of Wellesley, Vassar, Smith, and Mt. Holyoke in the late $19^{\text {th }}$ and early $20^{\text {th }}$ centuries (1932). All participants were "Old Americans", meaning of northwest European origin and of the so-called "white race", from higher SEPE classes, and of comparable age at the time of measurement. Bowles reported that stature and its components (lower limb and trunk lengths) increased from parents to offspring by a total of $0.8 \mathrm{~cm}$ per year. In contrast, pelvic breadth decreased, and shoulder breadth remained, essentially, constant. Bowles speculated that reasons for the change in body size and shape might be better health care, nutrition, climate change, assortative mating, and/or cultural modernization.
Ruff's reviews offer no definitive explanation for the allometry between height and skeletal breadth. Following Bowles' speculations, Ruff suggests that the increases measured in stature but not in bicristal or biacromial (shoulder) breadth may be related to nutrition or climate. This may be possible for the comparison of Japanese in Japan versus Hawaii, but it is unlikely for succeeding generations of Japanese in Japan or Belgians in Belgium. Neither the climate nor the diet changed so radically in the late $20^{\text {th }}$ century in these countries. Neither did the climate change appreciably in the northeastern United States, home to most of Bowles' Ivy League students. It is possible that diets did change as food production industrialized, as the new science of nutrition discovered essential nutrients, and as business, politicians, home economists, and moral preachers were all pointing Americans toward a new approach to diet. In her scientific-historical analysis of diet policy in the United States, Helen Zoe Veit (2013) argues that in the early $20^{\text {th }}$ century a diet revolution was taking place. This revolution was powered by propaganda from agro-business and government that there was a, "[...] moral mandate to rethink the rules by which Americans ate" (2013)(2013). American diets were changing because of the impact of these SEPE factors. Even so, a diet that increases bone length in the direction of standing height but decreases bone length/size for pelvic breadth is unknown. A more likely explanation of the impact of SEPE factors on skeletal allometry was offered by Scheffler and colleagues (Rietsch et al. 2013; Scheffler and Hermanussen 2014). These authors analyzed measurements of elbow breadth, pelvic breadth, and thoracic depth and breadth, of more than 28,000 healthy girls and boys aged 3 to 18 years who were participants in several anthropometric surveys carried out between 1980 (for all of the former German 
Democratic Republic) and 2012 in Potsdam and Berlin, Germany. The researchers reported that there was no increase in mean stature during this time period and no change in thoracic size, but there were biologically and statistically significant decreases in elbow and pelvic breadth. The researchers note that this skeletal change, "[...] coincides with the modern decline in upright locomotion" (Scheffler and Hermanussen 2014; Ruff 2002). By this they mean that the comforts of modern life lead to less development of muscle and skeleton needed for locomotion and manipulation hence narrower pelvis and elbow breadth. In Germany, as in most of the wealthier nations, young people experience less physical labor and, in general, less physical activity. Scheffler and colleagues report that only $13.1 \%$ of German girls and $17.4 \%$ of German boys are physically active for 60 min per day. In support of the association between physical activity and skeletal breadth the authors cite their own empirical analysis that the frame index (FI $=$ [elbow breadth / height] $\times 100$ ) is smaller with lower step counts in 6- to 10-year-old children.

What does SEPE have to do with step counts? The association is an outcome of the social, economic, political, and emotional relationship that people have with physical activity. As Scheffler and Hermanussen write, “[...] today, we connect with friends and relatives virtually via electronic media, we drive cars, use elevators, chauffeur our children to kindergartens and schools, and distances of up to $30 \mathrm{~km}$ per day as our ancestors did, are no longer walked by modern children and adolescents" (Scheffler and Hermanussen 2014, 594). Greater height and narrower frame size are outcomes of lifestyle, its material and moral foundations, and the prestige that members of a SEPE community enjoy by adhering to that lifestyle. When lifestyle factors are shared within the network of a SEPE class of people, then that community network grows to a characteristic size and shape. The 'shorter but stouter body of children of the lower social class' noted by Schlesinger and the 'more linearly built upper socio-economic classes' reported by Tanner are examples of this SEPE community effect.

\section{Example 2 - If you are told that you are a winner from infancy, then you will be taller as an adult}

The physiological pathways for a direct regulatory effect of dominance and subordination on growth remain unclear, but associations between SEPE status and neuroendocrine activity are well-known. Growth hormone $(\mathrm{GH})$ and insulin-like growth factor-1 (IGF-1) are the most potent regulators of skeletal growth and, generally, higher levels of these during the years of growth translate into greater height. GH and IGF-1 also have impacts to improve feelings of well-being and performance on cognitive tests. People with SEPE dominance tend to have higher levels of GH and IGF-1. Cortisol is a hormone released during times of physical or emotional stress. Cortisol can reduce growth in height because it is a GH/IGF-1 axis inhibitor. Lower SEPE status people tend to experience more adverse conditions of life when growing up, leading to more episodes of stress with high levels of cortisol release. Living in poverty is also associated with shallower increases of testosterone, in both boys and girls, at all stages of growth (Barch et al. 2020). Reduced testosterone may slow both skeletal growth and development of the hippocampus, the latter being important to emotion regulation. Based on a longitudinal study of participants aged from 3 to 19 years old, Barch and colleagues reported that those experiencing early life poverty had, "[...] disruptions 
in developmental testosterone trajectories and hippocampal volume growth across school age and adolescent development, as well as [...] greater emotion dysregulation and depression in adolescence $(2020,1)$. These SEPE-hormonal associations may explain differences in height between human communities. There are, however, some caveats as dominant individuals in some primate societies may be larger than subordinates and have higher levels of growth hormone, but also elevated cortisol (Maggioncalda et al. 2002; Maggioncalda et al. 2000). The opposing effects of GH and cortisol on growth may be mediated by testosterone. Dominant primates also have higher levels of testosterone, which can stimulate production of $\mathrm{GH}$ and perhaps over-ride the growth inhibition of cortisol. Social network analysis with human participants found that the more popular (i.e., socially dominant) members of a network had higher basal testosterone and lower basal cortisol (Ponzi et al. 2016). Once at the top of a dominance hierarchy, cortisol may decline and growth promoting hormones may be free to act. Adding to the complications is that fact that higher levels of testosterone or IGF-1 may be both a cause and consequence of dominant social position and feelings of emotional superiority. The existing data on in social hierarchies of male primates (Sapolsky and Spencer 1997; Sapolsky 2005) and on the effect of sport success in human women and men (Bogin et al. 2015) suggest this type of interactive regulation.

In wild baboons, social subordinance was associated with suppressed IGF-1 concentrations, but not concentrations of IGF-2 or IGF-binding protein. After eliminating other possible reasons, such as age, hyper-cortisol levels, testosterone, and food, Sapolsky and Spencer (1997) concluded that the social status differences in IGF-1 profiles were a consequence, rather than a cause, of the rank difference. In related research, Sapolsky documented a host of pernicious health consequences of social subordination in several primate species including humans. The severity of the health deficits arose from psychosocial factors and followed the social status gradient. Evidence that SEPE factors play an important role comes from qualitative studies which report that feeling poorly predicts poor health. Further SEPE involvement comes from quantitative economic research that finds people with poorer health suffer from greater income inequality. The feelings and the reality of poverty work synergistically to disrupt social networks and create decreased levels of trust and increased senses of alienation and disenfranchisement leading to a downward emotional spiral, depression, and hopelessness with negative consequences on health and height growth (these qualitative and quantitative studies are reviewed in Bogin.

Several colleagues and I tested the hypothesis that differences in SEPE status between groups of people within a community induce variation of IGF-1 levels and, by extension, growth in height (Bogin et al. 2015). The relationship between IGF-1, assessed via radioimmunoassay of fingerprick dried blood spot, and elite level sport competition outcomes were analyzed for a sample of 116 undergraduate men and women. Blood spots were taken 24 hours before a competition and 24 hours after the competition. There were no meaningful differences in mean IGF-1 assays between the sexes or between the sport practiced (lacrosse, handball, rugby, football (soccer), netball, and volleyball). There was a statistically significant difference between winners and losers of a competition. Winners, as a group, had higher average pre-game and post-game IGF-1 levels than losers (Table 1). Both winners and losers decreased in IGF-1 levels from the pre- to post-competition time points. We proposed the pregame differences in IGF-1 may serve as a 
proxy for physical dominance and feelings of social dominance, that is, the winning team had an overall feeing of superiority and this raised IGF-1 levels. We had also hypothesized that members of the same team would be more similar in IGF-1 levels than they were to players from other teams. This same-team community effect was not observed. Nevertheless, our findings provide some support toward the community effect in height hypothesis as acting through dominance and higher/break IGF-1.

We discussed our findings in relation to the action of the GH/IGF-1 axis as a transducer of multiple bio-social influences into a coherent signal which allows the growing human to adjust and adapt to local ecological conditions. IGF-1, closely interacts with the mechanistic Target of Rapamycin Complex 1 (mTORC1) signaling pathway (Figure 4). Research on this metabolic pathway was reviewed by Saxton and Sabatini (2017). They reported that mTORC1 is a master growth regulation pathway that is sensitive to the requirements for cell growth in terms of both hypertrophy and hyperplasia. IGF-1 and other growth promoting factors stimulate mTORC1 activity. The result is greater size of body cells, tissues, organs, and height. Various forms of stress, including nutrient and oxygen deficits as well as cortisol and other stress hormones, block the action of mTORC1 and inhibit cell enlargement and division. Moreover, active mTORC1 blocks cell autophagy, the self-destruction of body cells. Under stress mTORC1 is inactive and there

Table 1 Mean (SD) IGF-1 levels (g/L) 24 hours before and 24 hours after the game by win or lose

\begin{tabular}{|lcc|} 
& Win $\mathrm{n}=55$ & Lose $\mathrm{n}=46$ \\
\hline Before game & $47.8(14.8)$ & $43.1(14.9)$ \\
\hline After game & $46.8(16.5)$ & $42.8(14.3)$ \\
\hline Total mean IGF-1 & $46.2(13.8)$ & $41.6(12.4)$
\end{tabular}

$\mathrm{t}$-Test for difference in total mean IGF-1, $\mathrm{t}=3.5, \mathrm{p}=0.04$

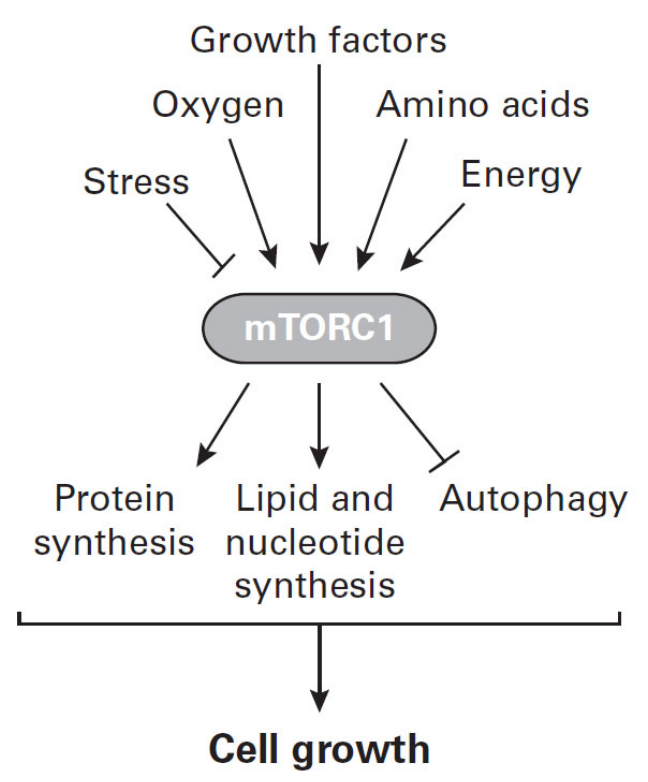

Figure 4 Basic elements of the mTORC1 signaling pathway. Hypertrophy and hyperplasia of cells requires the production of the cellular "building-blocks" (anabolic constituents) of proteins, lipids, and nucleotides while also suppressing catabolic pathways such as autophagy (destruction of cells). mTORC1 plays a central role in regulating these processes and therefore controls the balance between anabolism and catabolism in response to environmental conditions such as the supply of essential nutrients, oxygen, IGF-1, and other growth factors. Various forms of stress, including emotional stress that increases cortisol and other stress hormones, blocks the action of mTORC1. Adapted from Saxton \& Sabatini (2017).

is an increase in catabolism, including autophagy.

The extensive interacting matrix of variables that $\mathrm{mTORC} 1$ regulates throws additional light onto the mechanisms that allow for growth adjustments in terms of community effects in height and competitive growth. In socially upgraded communities of infants, children, and youth the complex interplay of between material and moral conditions and SEPE factors tends to stimulate height growth. In contrast, the offspring of socially downgraded communities are exposed to material, moral, and SEPE conditions that inhibit height growth. 


\section{Conclusion}

Since the 1990s there has developed a revised and expanded biocultural perspective of a recurring and seamless interaction between the biology of human development and the sociocultural environment. Not only does the latter influence the former, but human developmental biology modifies social and cultural processes as well. It is now understood that environmental forces, including many SEPE factors, regulate the expression of the genome as much, or more so, than any single nucleotide polymorphism (SNP) of DNA regulates the growth process. Some researchers hold on to the old notion of genetic determinism and even in the year 2020 claimed that about $80 \%$ of height is determined by genes (Kaiser 2020). Such claims are easily dismissed on biological and statistical grounds as they ignore current understanding of the complex nature of interactions between genome, epigenome, physical environment, and SEPE factors (Bogin 2021). Today we understand that growth, development, and maturation take place within a wide frame of possible outcomes and are not directed toward a narrow, so-called 'genetically determined' target.

SEPE dominance by communities of the upper classes, the elites, is maintained by a process called cultural inheritance (Cavalli-Sforza and Feldman 1973; Feldman and Ramachandran 2018). Cultural inheritance occurs in all human beings. It is the process by which parental phenotypes interact with offspring genomes to shape offspring phenotypes. The proponents of cultural inheritance, Luigi L. CavalliSforza (1922-2018), Marcus W. Feldman (b. 1942), and Sohini Ramachandran were/are biologists with specialization in human genetics and demography. As applied to human growth, the cultural inheritance model posits that upper classes and elites maintain a psychological and behavioral phenotype of high prestige (sensu, Cattell 1942) which gives rise to an emotional attitude of entitlement. The psychologicalemotional phenotype of the parents with high prestige is culturally transmitted to their offspring and interacts with offspring physiology to reduce negative stress and its growth inhibiting hormones, and to stimulate production of growth-promoting hormones. This parental-status-to-offspringgrowth pathway is a well-tested hypothesis that has been empirically documented in several non-human species, such as baboons (Sapolsky and Spencer 1997), mandrills (Setchell 2016), orangutans (Maggioncalda et al. 2002; Maggioncalda et al. 2000; Emery Thompson et al. 2012), mole rats (Young and Bennett 2010), meerkats (Huchard et al. 2016; Dubuc and CluttonBrock 2019; Russell et al. 2004), and other species (Clutton-Brock 2016).The human difference is culture, especially the ideological justifications for the dominance of wealthy elites to maintain their social position and their taller height. These ideological justifications are today enshrined in the hereditary aristocracies, constitutional monarchies, parliamentary monarchies, taxation laws, and other forms of antiegalitarian status differentials practiced in many of the wealthier North American, European, and Asian nations. The elites know that they are superior and are treated as such by the non-elites ( Bogin (2021) provides additional evidence and explanation). The physical and emotional stimulation operating through these community social networks, with positive stimulation for the elites and negative stimulation for the lower SEPE classes, maintain the gradients in height between elites and non-elites. 


\section{References}

Allen, E./Boisson, S./Cavill, S./Che, Y./Cumming, O./Dangour, A. D./Uauy, R./Velleman, Y./Watson, L. (2013). Interventions to improve water quality and supply, sanitation and hygiene practices, and their effects on the nutritional status of children. The Cochrane Database of Systematic Reviews (8). https://doi.org/10.1002/14651858.CD009382.pub2.

Barch, D. M./Shirtcliff, E. A./Elsayed, N. M./Whalen, D./Gilbert, K./Vogel, A. C./Tillman, R./Luby, J. L. (2020). Testosterone and hippocampal trajectories mediate relationship of poverty to emotion dysregulation and depression. Proceedings of the National Academy of Sciences of the United States of America 117 (36), 22015-22023. https://doi.org/10.1073/pnas.2004363117.

Baten, J./Blum, M. (2012). Growing tall but unequal: new findings and new background evidence on anthropometric welfare in 156 countries, 1810-1989. Economic History of Developing Regions 27 (sup1), 66-85. https://doi.org/10.1080/20780389.2012.657489.

Bents, D./Rybak, A./Groth, D. (2017). Spatial conscript body height correlation of Norwegian districts in the 19th century. Anthropologischer Anzeiger 74 (1), 65-69. https://doi.org/10.1127/anthranz/2017/0700.

Boas, F. (1892). The growth of children. Science 20 (516), 351-352. https://doi.org/10.1126/science.ns-20.516.351.

Boas, F. (1912). Changes in the bodily form of descendants of immigrants (14), 530-562. Available online at https://www.jstor.org/stable/659886.

Bogin, B. (2005). Patterns of human growth. 2nd ed. Cambridge, Cambridge University Press.

Bogin, B. (2021). Patterns of Human Growth. 3rd ed. Cambridge University Press.

Bogin, B./Hermanussen, M./Blum, W. F./Aßmann, C. (2015). Sex, Sport, IGF-1 and the Community Effect in Height Hypothesis. International Journal of Environmental Research and Public Health 12 (5), 4816-4832. https://doi.org/10.3390/ijerph120504816.

Bogin, B./Hermanussen, M./Scheffler, C. (2018). As tall as my peers - similarity in body height between migrants and hosts. Anthropologischer Anzeiger 74 (5), 365-376. https://doi.org/10.1127/anthranz/2018/0828.

Bogin, B./Scheffler, C./Hermanussen, M. (2017). Global effects of income and income inequality on adult height and sexual dimorphism in height. American Journal of Human Biology 29 (2). https://doi.org/10.1002/ajhb.22980.

Bowditch, H. P. (1877). The growth of children. Boston, Albert J. Wright.
Bowditch, H. P. (1891). The growth of children. studied by Galton's method of percentile grades. Boston.

Bowles, G. T. (1932). New types of old Americans at Harvard and at Eastern women's colleges. Cambridge, Harverd University Press.

Cattell, R. B. (1942). The concept of social status. The Journal of Social Psychology 15 (2), 293-308. https://doi.org/10.1080/00224545.1942.9921538.

Cavalli-Sforza, L. L./Feldman, M. W. (1973). Cultural versus biological inheritance: phenotypic transmission from parents to children. (A theory of the effect of parental phenotypes on children's phenotypes). American Journal of Human Genetics 25 (6), 618-637.

Christakis, N. A./Fowler, J. H. (2007). The spread of obesity in a large social network over 32 years. The New England Journal of Medicine 357 (4), 370-379. https://doi.org/10.1056/nejmsa066082.

Clutton-Brock, T. H. (2016). Mammal societies. Hoboken, New Jersey, Wiley Blackwell.

Dubuc, C./Clutton-Brock, T. H. (2019). Male immigration triggers increased growth in subordinate female meerkats. Ecology and Evolution 9 (3), 1127-1134. https://doi.org/10.1002/ece3.4801.

Duda, J. L./Chi, L./Newton, M. L./Walling, M. D/Catley, D. (1995). Task and ego orientation and intrinsic motivation in sport. International Journal of Sport Psychology 1 (26), 40-63.

Emery Thompson, M./Zhou, A./Knott, C. D. (2012). Low testosterone correlates with delayed development in male orangutans. PloS One 7 (10). https://doi.org/10.1371/journal.pone.0047282.

Feldman, M. W./Ramachandran, S. (2018). Missing compared to what? Revisiting heritability, genes and culture. Philosophical Transactions of the Royal Society of London. Series B, Biological Sciences 373 (1743). https://doi.org/10.1098/rstb.2017.0064.

Field, T. (1988). Stimulation of preterm infants. Pediatrics in Review 10 (5), 149-153. https://doi.org/10.1542/ pir.10-5-149.

Field, Tiffany M. (2007). The amazing infant. Oxford, Blackwell.

Froehlich, J. W. (1970). Migration and the plasticity of physique in the Japanese-Americans of Hawaii. American Journal of Physical Anthropology 32 (3), 429-442. https://doi.org/10.1002/ajpa.1330320313.

Gomula, A./Koziel, S./Groth, D./Bielicki, T. (2017). The effect of neighboring districts on body height of Polish conscripts. Anthropologischer Anzeiger 74 (1), 71-76. https://doi.org/10.1127/anthranz/2017/0701. 
Goudet, S. M./Bogin, B. A./Madise, N. J./Griffiths, P. L. (2019). Nutritional interventions for preventing stunting in children (birth to 59 months) living in urban slums in low- and middle-income countries (LMIC). The Cochrane Database of Systematic Reviews 6, CD011695. https://doi.org/10.1002/14651858.CD011695.pub2.

Harlow, H. F./Zimmermann, R. R. (1959). Affectional responses in the infant monkey; orphaned baby monkeys develop a strong and persistent attachment to inanimate surrogate mothers. Science 130 (3373), 421-432. https://doi.org/10.1126/science.130.3373.421.

Haymes, S. N./Haymes, M. V. de/Miller, R. J. (Eds.) (2017). The Routledge handbook of poverty in the United States / edited by Stephen Nathan Haymes, María Vidal de Haymes, and Reuben Jonathan Miller. London/New York, Routledge.

Heaney, S. (2000). Beowulf. A new verse translation. New York NY u.a., Norton.

Hermanussen, M./Alt, C./Staub, K./Aßmann, C./Groth, D. (2014). The impact of physical connectedness on body height in Swiss conscripts. Anthropologischer Anzeiger 71 (4), 313-327. https://doi.org/10.1127/0003-5548/2014/ 0466.

Hermanussen, M./Aßmann, C./Staub, K./Groth, D. (2016). Monte Carlo simulation of body height in a spatial network. European Journal of Clinical Nutrition 70 (6), 671-678. https://doi.org/10.1038/ejcn.2016.45.

Hermanussen, M./Bogin, B./Scheffler, C. (2017). Strategic growth adjustment. American Journal of Human Biology (8).

Hermanussen, M./Bogin, B./Scheffler, C. (2018). Stunting, starvation and refeeding: a review of forgotten 19th and early 20th century literature. Acta Paediatrica 107 (7), 1166-1176. https://doi.org/10.1111/apa.14311.

Hermanussen, M./Bogin, B./Scheffler, C. (2019). The impact of social identity and social dominance on the regulation of human growth: a viewpoint. Acta Paediatrica 108 (12), 2132-2134. https://doi.org/10.1111/apa.14970.

Hermanussen, M./Bogin, B./Scheffler, C. (2020). The regulation of human growth includes an understanding of competitive growth strategies and community effects on height. American Journal of Human Biology 32 (3), e23383. https://doi.org/10.1002/ajhb.23383.

Hermanussen, M./Scheffler, C. (2016). Stature signals status: the association of stature, status and perceived dominance - a thought experiment. Anthropologischer Anzeiger 73 (4), 265-274. https://doi.org/10.1127/anthranz/2016/0698.

Huchard, E./English, S./Bell, M. B. V./Thavarajah, N./Clutton-Brock, T. (2016). Competitive growth in a cooperative mammal. Nature 533 (7604), 532-534. https://doi.org/10.1038/nature17986.
Huxley, J. S. (1932). Problems of relative growth. London, Methuen and Co., Ltd.

Kaiser, J. (2020). 'Landmark' study resolves a major mystery of how genes govern human height. Available online at https://www.sciencemag.org/news/2020/11/ landmark-study-resolves-major-mystery-how-genesgovern-human-height.

Koehly, L. M./Loscalzo, A. (2009). Adolescent obesity and social networks. Preventing Chronic Disease 6 (3), A99.

Komlos, J. (2009). Anthropometric history: an overview of a quarter century of research. Anthropologischer Anzeiger 67 (4), 341-356. https://doi.org/10.1127/0003$5548 / 2009 / 0027$.

Komlos, J./Tanner, J. M./Davies, P. S./Cole, T. (1992). The growth of boys in the Stuttgart Carlschule, 1771-93. Annals of Human Biology 19 (2), 139-152. https://doi.org/10.1080/03014469200002022.

Koziel, Slawomir/Zaręba, Monika/Bielicki, Tadeusz/Scheffler, Christiane/Hermanussen, Michael (2019). Social mobility of the father influences child growth: A three-generation study. American Journal of Human Biology 31 (4). https://doi.org/10.1002/ajhb.23270.

Lebedeva, Lidia/Groth, Detlef/Hermanussen, Michael/Scheffler, Christiane/Godina, Elena (2019). The network effects on conscripts' height in the central provinces of Russian empire in the middle of XIX century - at the beginning of XX century. Anthropologischer Anzeiger 76 (5), 371-377. https://doi.org/10.1127/anthranz/2019/0984.

Liebig, Stefan (2012). Richard Wilkinson and Kate Pickett (2009): the spirit level. why more equal societies almost always do Better. Allen Lane, London. Social Justice Research 25 (1), 102-107. https://doi.org/10. 1007/s11211-012-0148-9.

López-Blanco, M. (1995). Growth as a mirror of conditions of a developing society. the case of Venezuela. In: R. Hauspie/G. Lindgren/F. Falkner (Eds.). Essays on auxology. London, Castlemead Publications, 313-321.

Maggioncalda, A. N./Czekala, N. M./Sapolsky, R. M. (2000). Growth hormone and thyroid stimulating hormone concentrations in captive male orangutans: Implications for understanding developmental arrest. American Journal of Primatology 50 (1), 67-76. https:// doi.org/10.1002/(sici)1098-2345(200001)50:1\%3C67::aidajp6\%3E3.0.co;2-v.

Maggioncalda, A. N./Czekala, N. M./Sapolsky, R. M. (2002). Male orangutan subadulthood: a new twist on the relationship between chronic stress and developmental arrest. American Journal of Physical Anthropology 118 (1), 25-32. https://doi.org/10.1002/ajpa.10074. 
Marmot, M./Bell, R. (2012). Fair society, healthy lives. Public Health 126 Suppl 1, S4-S10. https://doi.org/10.1016/j.puhe.2012.05.014.

Martire, L. M./Franks, M. M. (2014). The role of social networks in adult health: introduction to the special issue. Health Psychology : Official Journal of the Division of Health Psychology, American Psychological Association 33 (6), 501-504. https://doi.org/10.1037/hea0000103.

Mauss, M. (1967). The gift. forms and functions of exchange in archaic societies. New York, W. W. Norton.

Meyer, J. S./Novak, M. A./Bowman, R. E./Harlow, H. F. (1975). Behavioral and hormonal effects of attachment object separation in surrogatepeer-reared and mother-reared infant rhesus monkeys. Developmental Psychobiology 8 (5), 425-435. https://doi.org/10.1002/dev.420080507.

Mumm, R./Czernitzki, A.-F./Bents, D./Musalek, M. (2017). Socioeconomic situation and growth in infants and juveniles. Anthropologischer Anzeiger 74 (2), 101-107. https://doi.org/10.1127/anthranz/2017/0706.

NCD Risk Factor Collaboration (2016). A century of trends in adult human height. eLife 5. https://doi.org/10.7554/elife.13410.

Peiper, A. (1955). Chronik der Kinderheilkunde. Leipzig, VEB Georg Thieme Verlag.

Ponzi, D./Zilioli, S./Mehta, P. H./Maslov, A./Watson, N. V. (2016). Social network centrality and hormones: The interaction of testosterone and cortisol. Psychoneuroendocrinology 68, 6-13. https://doi.org/10.1016/j.psyneuen.2016.02.014.

Rietsch, K./Eccard, J. A./Scheffler, C. (2013). Decreased external skeletal robustness due to reduced physical activity? American Journal of Human Biology 25 (3), 404-410. https://doi.org/10.1002/ajhb.22389.

Rogol, A. D. (2020). Emotional deprivation in children: growth faltering and reversible hypopituitarism. Frontiers in Endocrinology 11. https://doi.org/10.3389/fendo.2020.596144.

Rueden, C. von/Gurven, M./Kaplan, H. (2008). The multiple dimensions of male social status in an Amazonian society. Evolution and Human Behavior: Official Journal of the Human Behavior and Evolution Society 29 (6), 402-415. https://doi.org/10.1016/j.evolhumbehav.2008.05.001.

Ruff, C. (1994). Morphological adaptation to climate in modern and fossil hominids. American Journal of Physical Anthropology 37 (S19), 65-107. https://doi.org/10.1002/ajpa.1330370605.
Ruff, C. (2002). Variation in human body size and shape. Annual Review of Anthropology 31 (1), 211-232. https://doi.org/10.1146/annurev.anthro.31.040402.085407.

Russell, A. F./Carlson, A. A./McIlrath, G. M./Jordan, N. R./Clutton-Brock, T. (2004). Adaptive size modification by dominant female meerkats. Evolution; International Journal of Organic Evolution 58 (7), 1600-1607. https:// doi.org/10.1111/j.0014-3820.2004.tb01739.x.

Sapolsky, R. M. (2005). The influence of social hierarchy on primate health. Science 308 (5722), 648-652. https://doi.org/10.1126/science.1106477.

Sapolsky, R. M./Spencer, E. M. (1997). Insulin-like growth factor I is suppressed in socially subordinate male baboons. The American Journal of Physiology 273 (4), R1346-51. https://doi.org/10.1152/ajpregu.1997.273.4.r1346.

Saxton, R. A./Sabatini, D. M. (2017). mTOR Signaling in Growth, Metabolism, and Disease. Cell 168 (6), 960-976. https://doi.org/10.1016/j.cell.2017.02.004.

Scheffler, C./Hermanussen, M. (2014). Is there an influence of modern life style on skeletal build? American Journal of Human Biology 26 (5), 590-597. https://doi.org/10.1002/ajhb.22561.

Scheffler, C./Hermanussen, M./Bogin, B./Liana, D. S./Taolin, F./Cempaka, P. M. V. P./Irawan, M./Ibbibah L. F./Mappapa, N. K./Payong, M. K. E./Homalessy, A. V./Takalapeta, A./Apriyanti, S./Manoeroe, M. G./Dupe, F. R./Ratri, R. R. K./Touw, S. Y./K, P. V./Murtani, B. J./Nunuhitu, R./Puspitasari, R./Riandra, I. K./Liwan, A. S./Amandari, P./Permatasari, A. A. I./Julia, M./Batubara, J./Pulungan, A. (2020). Stunting is not a synonym of malnutrition. European Journal of Clinical Nutrition 74 (3), 377-386. https://doi.org/10.1038/s41430-019-0439-4.

Schell, Lawrence M./Gallo, Mia V./Ravenscroft, Julia (2009). Environmental influences on human growth and development: historical review and case study of contemporary influences. Annals of Human Biology 36 (5), 459-477. https://doi.org/10.1080/03014460903067159.

Schlesinger, E. (1925). Das Wachstum des Kindes. In: F. Kraus/Erich Meyer/O. Minkowski et al. (Eds.). Ergebnisse der inneren Medizin und Kinderheilkunde. Berlin, Heidelberg, Springer Berlin Heidelberg, 456-579.

Sen, Amartya (2002). Why health equity? Health Economics 11 (8), 659-666. https://doi.org/10.1002/hec.762.

Setchell, J. M. (2016). Sexual selection and the differences between the sexes in Mandrills (Mandrillus sphinx). American Journal of Physical Anthropology 159 (Suppl 61), 105-129. https://doi.org/10.1002/ajpa.22904.

Sikdar, M. (Ed.) (2015). Human growth. The mirror of the society. Delhi, B.R. Publishing Corporation. 
Solomons, N. W. (2019). Vision of research on human linear growth. Food and Nutrition Bulletin 40 (4), 416-431. https://doi.org/10.1177/0379572119885475.

Spitz, R. A. (1945). Hospitalism; an inquiry into the genesis of psychiatric conditions in early childhood. The Psychoanalytic Study of the Child 1, 53-74.

Steckel, R. H. (2017). Social and Economic Effects on Growth. In: N. Cameron/L. Schell (Eds.). Human growth and development. 2nd ed. Cambridge, Massachusetts, Vereinigte Staaten, Elsevier Academic Press, 225-244.

Stulp, Gert/Buunk, A. P./Verhulst, S./Pollet, T. V. (2012). High and mighty: height increases authority in professional refereeing. Evolutionary Psychology 10 (3). https://doi.org/10.1177/147470491201000314.

Stulp, Gert/Buunk, A. P./Verhulst, S./Pollet, T. V. (2013). Tall claims? Sense and nonsense about the importance of height of US presidents. The Leadership Quarterly 24 (1), 159-171. https://doi.org/10.1016/j.leaqua.2012.09.002.

Stulp, Gert/Buunk, A. P./Verhulst, S./Pollet, T. V. (2015). Human height is positively related to interpersonal dominance in dyadic interactions. PloS One 10 (2), e0117860. https://doi.org/10.1371/journal.pone.0117860.

Tajfel, H./Turner, J. C. (2004). The social identity theory of Intergroup behavior. In: J. T. Jost/J. Sidanius (Eds.). Political Psychology. Psychology Press, 276-293.

Takahashi, E. (1986). Secular trend of female body shape in Japan. Human biology 2 (58), 293-301.
Tanner, J. M. (1962). Growth at adolescence. With a general consideration af the effects of hereditary and environmental factors upon growth and maturation from birth to maturity. 2nd ed. Oxford, Blackwell Scientific Publications.

Tanner, J. M. (1987). Growth as a mirror of the condition of society. secular trends and class distinctions. Acta paediatrica Japonica : Overseas edition 29 (1), 96-103. https://doi.org/10.1111/j.1442-200x.1987.tb00015.x.

Thompson, D. W. (1917). On growth and form. Cambridge, Cambridge University Press.

Thompson, D. W. (1942). On growth and form. a new edition. Cambridge, Cambridge University Press.

Veit, H. Z. (2013). Modern food, moral food. self-control, science, and the rise of modern American eating in the early twentieth century. Chapel Hill, The University of North Carolina Press.

Vercauteren, M./Hauspie, R./Susanne, C. (1998). Biometry of Belgian boys and girls. changes since Quételet. Secular Growth Changes in Europe, 47-63.

Young, A. J./Bennett, N. C. (2010). Morphological divergence of breeders and helpers in wild Damaraland molerat societies. Evolution; International Journal of Organic Evolution 64 (11), 3190-3197. https://doi.org/10.1111/j. 1558-5646.2010.01066.x. 